\title{
“THE LANDS END OF INDIA" - KANYAKUMARI
}

\author{
Dr. A.D. PADMASREE
}

Assistant Professor, Department of History, Jayaraj Annapackiam College for Women (Autonomous), Periyakulam, India

\section{ABSTRACT}

Kanyakumari district has derived its name, from the township kanyakumari, also known as the Cape Comorin. Kanyakumari district forms a part of the Sangam era. Subsequently Venad came to be known as Travancore. Travancore is the Anglicized form of Tiruvithankur a word derived from Tiruvtamcode. The present Kanyakumari district was formed on 1 November 1956 as a result of the re-organisation of states on linguistic basis. There is no large scale industry in the district but cottage industries contribute mush to prosperity of the people. Hand loom-weaving is a major industry pursued by many in all the taluks. The administrative set up of the area is slightly different from that obtaining in the Madras state. Each taluk is divided into revenue villages called pakuthies which are under the charge of village officers. There are extensive palmyra grove in the plains of these taluks, and beautiful coconut grove near the sea coast and along the banks of the rivers. Jack, Mango,Tamarind, Cashew and other trees grow largely in the interior plantains and of different varieties are cultivated on a large scale particularly on hill slopes. The canal, which serves areas in the Madras state is known as the “Kanyakumari Canal"and it takes off from mile 24 of Neyyar left bank canal. The Kerala state agreed to maintain a supply of 150 acres of water into this canal near the place at Kaliyakkavilai where the left bank canal enters Madras state. Kanyakumari district, "The lands end of India" is, by nature, a gifted area.

KEYWORDS: Administration, Canal, Industry, Village and Cultivation

Received: Jan 22, 2020; Accepted: Feb 12, 2020; Published: Feb 27, 2020; Paper Id.: IJMPERDFEB202087

\section{INTRODUCTION}

Kanyakumari district has derived its name, from the township kanyakumari, also known as the Cape Comorin. Kanyakumari district forms a part of the Sangam era. Subsequently Venad came to be known as Travancore. Travancore is the anglicized form of Tiruvithankur a word derived from Tiruvithamcode. The rulers of Tranancore who trace their descent from the famous Chera dynasty rules the country with Padmanabhapuram in Kalkulam taluk as their capital. Marthandavarma, the maker of modern Travancore who ascended the throne in 1729 A.D. He conquered the various Rajas who were ruling over the territories lying north, and extended the boundary of Travancore. The present Kanyakumari district was formed on 1 November 1956 as a result of the Re-organisation of States on linguistic basis.

\section{PHYSICAL FEATURES}

The district has an area of 645.5 sq.miles and the population of 18,70,380. More than eighty seven percent of the people speak Tamil. The district comprises Vilavancode, Kalkulam, Thovalai and Agasteeswaram taluks, and bounded on the north by Tirunelveli district, east by Tirunelveli district and Bay of Bengal,west by Neyyatinkara taluk of Kerala State and in the south by the Arabian sea. 
The administrative set up of the area is slightly different from that obtaining in the Madras State. Each taluk is divided into revenue villages called pakuthies which are under the charge of village officers. There are extensive palmyra grove in the plains of these taluks, and beautiful coconut grove near the sea coast and along the banks of the rivers. Jack, Mango,Tamarind, Cashew and other trees grow largely in the interior. Plantains and Tapioca of different varieties are cultivated on a large scale particularly on hill slopes. The tract of the country comprising of Agasteeswaram and Thovala taluks commonly known as Nanjilnad. It is famous for paddy fields. There are salt pans from early times in Agasteeswaram and Kalkulam taluks.

\section{INDUSTRIES}

There is no large scale industry in the district but cottage industries contribute mush to prosperity of the people. Hand loom-weaving is a major industry pursued by many in all the taluks. This cottage industry is concentrated in places such as Kottar, Vadaseri, Elangadai, Eraniel, Palliyadi and Valvachagoshtam. In olden days this industry was not only meeting the entire cloth requirement of the districts, but also exporting large quantities to other parts of India and abroad.

A sales emporium has also been opened at Nagercoil to popularized the handloom fabrics .In the emporium, quality produced in different parts of the state, including kanyakumari district, are sold at low prices. Cashew nut processing is predominantly an export - oriented seasonal industry. The national nut company at Palugal, the Vijayalakshmi cashew industries and the Raju vilas roasting plant at palavilai are the main units in the district.

Lace-making is an important cottage industry, organized and conducted by the Christian missionary institution providing employment to a large number of women. Poultry-keeping and Bee-keeping are carried on in the Y.M.C.A at Marthandam and its surrounding places.

The Marthandam rural recreation centre has an all India reputation. It has to its credit a lot of pioneering work in the field of rural up - lift and has produced inspiration and lead to many places in and outside India. Jaggery-making and weaving of mats out of palmyra leaves are mostly confined to Kalkulam and Vilavancode taluks. Fishing is one of the important source for the people of the coastal areas.

\section{TEMPLES}

The four taluks contain many relics of archaeological and historical interest. Many inscriptions have been recovered from temples and palaces at Cape Comerin, Suchindram, Udayagiri and Padmanabhapuram. Other places of similar interest are the rock-cut temples at Chitharal and Utachitkottai in Vivancode taluk.

\section{FESTIVALS}

The car festival in Suchindram temple, the kodai festivel in the Mandakadu temple , the Thirukalyan celebration in the Kumarakoli temple in Kalkulam taluk are the most important Hindu festivals. The chandanakudam in the Mosque at Thuckalai is a grand Muslim festival. The annual festival in St.Xavier's church at Kottar is usually celebrate on a lavish scale.

\section{THE ANCIENT GLORY}

Patmanabhapuram was the capital of Travancore until about a few centuries ago. It is now the Revenue Divisional Headquarters. Padmanabhapuram palace is surrounded by a square stone fortification . There is a cot made of numerous 
types of wood on which the Maharaja used to sleep. Cape Comorin is a famous place of pilgrimage and is the only place where one can enjoy the unique sight of sunrise and sunset at the confluence of the three seas. The very ancient temple dedicated to the Virgin goddess Bhagavathi. Another notable sight is the eighteenth century fortress of Vattakottai overlooking the sea.

\section{RARE SANDS AND RIVERS}

The sea sand in and around Cape Comerin and Manavalakurichi in Kalkulam Taluk contains valuable "Rare earth" minerals such as Monoxide, Zircon, Garnet, Ilmenite, etc. Two rivers Kothayar and Pazhayar flows through this district. The Kothayar which is also known as Tambraparani river, it flows through the two taluks of Kalkulam and Vilavancode and reaches the sea at Thengapattanam. The total length of the river is 37 miles. The Pazhayar flows through the taluks of Thovala and Agasteeswaram and reaches at the Manakudy lake after a course of 23 miles.

The river Kothayar is dammed at Pechiparai and the Paraliar, which is a tributary of Kothayar is dammed at Perinchani and these two projects are designed to irrigate about 65,000 acres of paddy fields in Nanjil nad in Kalkulam.

\section{KANYAKUMARI CANAL}

The canal, which serves areas in the Madras state is known as the "Kanyakumari Canal" and it takes off from mile 24 of Neyyar left bank canal. The Kerala state agreed to maintain a supply of 150 acres of water into this canal near the place at Kaliyakkavilai where the left bank canal enters in Madras state. The Kanyakumari canal is a peculiar one. It had to be laid in deep cuttings at ridges and in embankments of valleys. The depth of the cutting in some place is 96 feet. Six branches take off from the kanyakumari canal, the most important and longest of there being the Mulliyar branch.

Another one canal known as A.V.M.canal which runs from Trivandrum to Thengapattanam covering a distance of $21 \mathrm{~km}$. Which $8.8 \mathrm{~km}$ the stretch between Thengapattanam to Neerodi lies within the Tamilnadu state.

\section{CONCLUSIONS}

Kanyakumari district, "the lands end of India" is, by nature, a gifted area. It was the "granary" of the erstwhile Tranvancore State, before the re-organisation of states. Nevertheless, even in this evergreen district, there are some dry patches, the aim of the second stage of the Neyyar Project is to make these dry patches also fertile and productive.

\section{REFERENCES}

1. Kanyakumari district Gazeteer, (1995), Madras.

2. Madras Information, (1957), Madras.

3. Madras State Administrative Report, (1956), Madras.

4. Kerala State Administation Report, (1956), Trivandrum

5. Nagamiya, V., (1906), The Thavacore State Manual, Vol.- I, Thivandrum.

6. Edgar Thurston, (1972), Caste and Tribes in South India, Vol. - I, Delhi.

7. Daniel, D., (1985), Struggle for Responsible Government in Travancore,

8. 1938-1947, Madurai.

9. Zachariah, V., (1901), The Pioneer Missionary Works in Travancore, Nagercoil. 
10. Padmanabha Iyar, A., (1941), Modern Travancore, Part - I, Trivandrum. 